UDC 622.673.6:539.4

I.V.Belmas ${ }^{1}$, Dr. Sc. (Tech.), Prof., orcid.org/0000-0003-2112-0303,

D. L. Kolosov ${ }^{2}$, Dr. Sc. (Tech.), Assoc. Prof., orcid.org/0000-0003-0585-5908,

A. L. Kolosov ${ }^{3}$, Cand. Sc. (Tech.), Assoc. Prof., orcid.org/0000-0001-7678-9341,

S.V. Onyshchenko ${ }^{2}$,

orcid.org/0000-0002-5709-7021
DOI: $10.29202 /$ nvngu/2018-2/5

1 - Dniprovsk State Technical University, Kamianske, Ukraine, e-mail: belmas09@meta.ua

2 - National Mining University, Dnipro, Ukraine, e-mail: evolyuta@gmail.com

3 - JSC "Constanta”, Korolyov, Russian Federation, e-mail: globoid@mail.ru

\title{
STRESS-STRAIN STATE OF RUBBER-CABLE TRACTIVE ELEMENT OF TUBULAR SHAPE
}

Purpose. Establishment of dependencies of the stress-strain state of a rubber-cable rope on its mechanical parameters and geometric parameters of a part where a flat rope gets a tubular shape considering the influence of a cable base breakage.

Methodology. Construction of analytic models of interaction of cables within a rubber-cable rope as a composite structure, created from parallel cables regularly placed in one plane that interact through a layer of rubber, using the methods of mechanics of composite materials. Obtaining analytical dependencies in closed form for establishing the parameters of a stress-strain state of a rope in a part where it gets a tubular shape, which allows determining upper and lower boundaries of stresses in cables and in a rubber layer of a rope. Mathematical formulation of the process is based on the principles of mechanics of layered structures with hard and soft layers.

Findings. Two mathematical models were developed and investigated, which allows defining the boundaries of a stress-strain state of a flat rubber-cable rope which gets a spatial shape of a cylinder. Obtained results allow predicting running abilities of a rope with a high level of reliability including brakeages of its reinforcing cables.

Originality. Analytical dependencies for boundary values of rigidity characteristics of a rubber inter-cable layer were obtained and solved, which allows determining basic characteristics of a stress-strain state of the rope, which gets a shape of a pipe within the limited length including the case of a cable base breakage.

Practical value. The possibility to determine the boundaries of a stress-strain state of a rope, prediction of its stress state in case of cable breakage during operation, allows reasonable choosing of the parameters of lifting and transporting machines, on which the rope gets a tubular shape. This increases the level of their operation safety and contributes to solving the problem of ecological compatibility of underwater oil extraction by removing the oil from the area of the well damage directly through the rope cavity, which gets a cylinder shape and which has a massive oil-receiving unit attached.

Keywords: flat rubber-cable rope, transitional rope part, longitudinal load, cable base breakage, stress-strain state, lifting and transporting machine

Introduction. Designs of modern machines, equipment and mechanisms of mining [1-4], transport [5, 6] and technology engineering [7-9] are being continuously developed and improved in the direction of increasing the productivity, reliability, strength and energy efficiency.

Flat rubber-cable belts (RCB) and ropes (RCR) are widely used in mining and metallurgic engineering [10, 11]. In particular, ropes in special conveyors are shaped into a spatial tube [12]. A rope of tubular shape is suggested to be used in mineral extraction systems [13, 14] that use an airlift $[15,16]$ to protect the water environment from oil leakage during its underwater extraction $[17,18]$. Introduction of technical solutions, connected with the usage of belts and ropes, which get a tubular shape, is constrained by the lack of methods for determining their stress state, including the case of cable breakage.

State of question and statement of research problem. To simplify the report of the subject, the belt and the rope will hence be called 'the rope' for convenience. Giving a flat rope tubular shape is accompanied by an

(C) Belmas I. V., Kolosov D. L., Kolosov A. L., Onyshchenko S. V., 2018 uneven distribution of forces between its cables. An uneven distribution of forces leads to the curvature of flat cross-sections of the rope and the occurrence of shear stress in its shell. The breakage of the rubber shell is not just dangerous because of a lost connection between the cables. It can also lead to aggressive water leakage to cables, their corrosion and breakage.

The structure of the cable, as a system of twisted wires, leads to a twisting moment of the rope. Distribution of forces in a cross-section of the rope impacts the strength, twisting equilibrium and operation safety of rubber-cable ropes. It depends on the parameters of the rope (belt) and the part where it gets a spatial shape. The establishment of quantitative characteristics of the stress-strain state (SSS) of a rubber-cable rope during its spatial deformation under the action of external load is an actual scientific and technical problem. The solution of it will allow reasonable selection of parameters of the transitional part and the entire rope, ensure its strength and operation safety. The application of tubular-shaped ropes will contribute to solving the actual problem of ecological compatibility of underwater mineral extraction, including oil extraction. 
The flat rubber-cable rope consists of a cable system that is put in an elastic shell and arranged parallel in one plane. The shell can be made of rubber or other elastomer. The shell material will hence be called 'the rubber'. It protects the cables from the influence of external environment, the interaction with the material being transported and elements of the machine it is installed on. The issue of a stress-strain state of a flat rope in the part where a flat rope gets a tubular shape was investigated in the paper [19]. There are no guidelines for calculating a rope and limits of their application. Papers $[10,11]$ are devoted to the issue of a stress state of a flat rubber-cable rope with cable breakage. The stress-strain state of a flat rope as a composite structure with soft and hard layers was considered there. The hard layers take tensile forces, the soft only take a shear stress.

Presentation of main research. Rubber-cable rope with a part where it gets a tubular shape is depicted in Fig. 1.

Cables have a significant tensile rigidity compared to rubber. The rubber provides constructive integrity and mechanical interaction of the tractive element system. It creates a continuous body of the rope.

The interaction of cables is determined by normal and tangential stresses in rubber layers, as in elements of composite material. The first appear in the presence of relative displacement of cables in the planes normal to them. Tangential stresses appear due to a mutual shift of cables along their axes. The stresses depend on displacements of cables and rigidity of rubber layers.

The problem of determining the stresses in a rubbercable rope in a part where it gets a tubular shape is geometrically nonlinear. It is related to the determination of a mechanism of mutual deformation of all elements of the rope, including rubber layers, as components of a composite structure. In order to simplify the problem, determine not the stress-strain state, but the boundaries of possible values of stresses that may occur in the elements of the rope by giving it a tubular shape.

The boundaries of these values are determined by the shape that the rope cables get. In the cross-section of the rope running on (off) the drum and behind it the centers of cables are located along straight lines. The

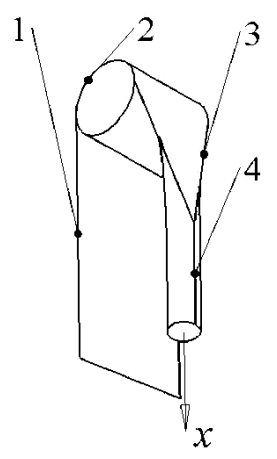

Fig. 1. Rope with a part of tubular shape:

1 - a flat part of a rope; 2 - a part of a rope interaction with a drum; 3 - a part where a flat rope gets a tubular shape; 4-a part of a tubular-shaped rope cable placement spacing is constant. The rubber located between the cables does not deform in a plane of the rope. The centers of cables are located on concentric circles in the cross-sections of completion of giving a cylindrical shape and the following cross-sections. The rubber between the cables is deformed along a circle arc. The angular spacing of cable placement is constant.

Significant changes in a distance between the cables in cross-sections of the rope occur in the part between the part of giving the cross-section of the rope a circular shape and the part of running-on (off) the drum. In this transitional part the cables get curvilinear shape. There is a compression stress in the rubber located between the cables. The rigidity of rubber in such compression affects the displacement of cables in a cross-section of the rope, curvature and internal forces of their tension respectively. Boundaries of a stressed state can be determined by considering two cases, taking the rigidity of the rubber between the cables in compression by the cables infinitely large and infinitely small.

Consider the case where the distances between the centers of adjacent cables remain unchanged in the cross-sections normal to axis of the rope. That is, the compression rigidity of rubber layers is considered infinitely large.

As indicated above, in a cross-section of running on the drum and behind it the cables are located along a straight line. Number the cables $\pm 1, \pm 2, \pm 3, \ldots, \pm M / 2$. Perform the displacement of cables in a cross-section of completion of a part of giving a cylindrical shape, in a plane normal to the axis of the rope. Turn the centers of cables numbered $i \neq \pm 1$ around the first by the angles $a= \pm \frac{\pi}{M}$. The centers of cables numbered $i= \pm 2$ are located along the circle with a radius

$$
R=\frac{t M}{2 \pi} .
$$

Repeat the turns around the next cable centers by the same angles. Provide the placement of all the cable centers along the circle (Fig. 2).

The displacements of ends of discrete cables occur in in circle arcs. For infinitely small cable placement spacing it occurs along evolvents. The distance between them is constant. It is equal to the cable placement spacing. Trace normal cylindrical surfaces through the movement trajectories of cable centers. Choose the

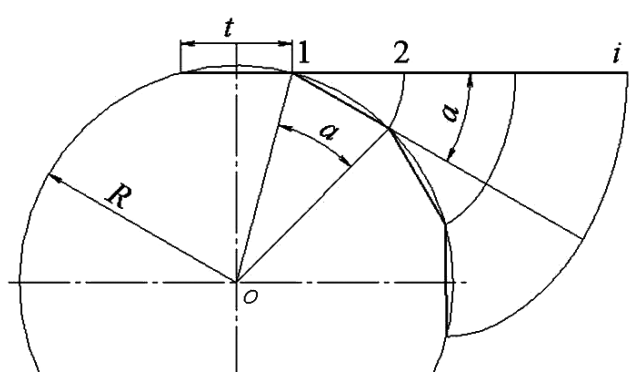

Fig. 2. The diagram of the cable displacement in the part of completion of giving a cylindrical shape to the rope 
height of surfaces equal to the length of a part of completion of giving a cylindrical shape to the rope $-L$.

Pairs of points are located on the formed surfaces that correspond to coordinates of placement of cable centers at the boundaries of a part of completion of giving a cylindrical shape to the rope. Trace geodesic curves between the points - curves of minimum length. Note that minimum lengths of deformed cables correspond to the minimum work of their deformation. Unfold the formed cylinders with the geodesic lines. Involutes of these lines are straight lines. Write lengths of the lines in the following form

$$
L_{i}=\sqrt{\left\{\frac{2 \pi}{M} t \sum_{j=1}^{i-1}(i-j)\right\}^{2}+L^{2}} .
$$

Relative elongations of cables do not depend on coordinate $x$

$$
\varepsilon_{1, \pm i}=\frac{\sqrt{\left[\frac{2 \pi}{M} t \sum_{j=1}^{i-1}(i-j)\right]^{2}+L^{2}}-L}{L} .
$$

Consider the symmetry of rope deformation. Expand relative elongations in Fourier series in cosines

$$
f_{i}=\frac{1}{M}\left[\begin{array}{l}
\sum_{k=1}^{M-1} \varepsilon_{1, k}+2 \sum_{m=1}^{M-1} \sum_{k=1}^{M-1} \varepsilon_{1, k} \cos \left(\mu_{m}(k-0.5)\right) \times \\
\times \cos \left(\mu_{m}(i-0.5)\right)
\end{array}\right]
$$

where $\mu_{m}=\frac{\pi m}{M}$.

The rope length significantly exceeds the length of the part of interaction with a drum. Neglect it. Consider a rope consisting of two infinitely long segments. There is a part between them where a flat rope gets a tubular shape that has a length $L$. As shown above, relative elongations of cables are constant along the axis of the rope. Accordingly, the deformation of the rope occurs symmetrically respectively to the middle of the part where its cross-section changes the shape. Place the beginning of the $x$-axis in the middle of the specified part.

Deformed, and respectively, stressed state of the rope has two planes of symmetry. This allows determining the state of the fourth part of a rope. This rope part has a part where a rope gets a tubular shape. Give it the number 1 , and give the adjacent number 2 . These numbers are used to indicate the parameters related to respective parts. Formulate boundary conditions for the accepted physical model

$$
\begin{gathered}
x=0, \quad u_{1, i}=0 ; \\
x \rightarrow \infty, \quad u_{2,1}=u_{2,2}=\ldots=u_{2, M}, \quad p_{2, i}=P,
\end{gathered}
$$

and the conditions of joint deformation of rope parts

$$
x=L / 2 ; \quad u_{1, i}=u_{2, i} ; \quad p_{1, i}=p_{2, i},
$$

where $P$ is the average force of tension of cables - a part of an external load, that affects one cable.

Considering the generally accepted assumptions concerning the character of deformation of rubber-ca- ble rope components as a composite material with significantly different moduli of elasticity of its components [19] and boundary conditions (2), accept the following forms of solutions

$$
\begin{gathered}
u_{1, i}=\sum_{m=1}^{M-1} A_{m}\left(e^{\beta_{m} x}-e^{-\beta_{m} x}\right) \cos \left(\mu_{m}(i-0.5)\right)+\frac{P x}{E F} \\
p_{1, i}=E F \sum_{m=1}^{M-1}\left(\begin{array}{c}
A_{m}\left(e^{\beta_{m} x}+e^{-\beta_{m} x}\right) \beta_{m}+ \\
+\frac{2}{M} \sum_{k=1}^{M-1} \varepsilon_{1, k} \cos \left(\mu_{m}(k-0.5)\right)
\end{array}\right) \times \\
\times \cos \left(\mu_{m}(i-0.5)\right)+P \\
u_{2, i}=\sum_{m=1}^{M-1} B_{m} e^{-\beta_{m} x} \cos \left(\mu_{m}(i-0.5)\right)+\frac{P x}{E F} \\
p_{2, i}=P-E F \sum_{m=1}^{M-1} B_{m} e^{-\beta_{m} x} \beta_{m} \cos \left(\mu_{m}(i-0.5)\right)
\end{gathered}
$$

where $u_{i}, p_{i}$ - displacement of a cross-section of cable $i$ along the rope and its inner force of tension resistance; $M$ - the amount of cables in a rope; $E, F-$ reduced modulus of elasticity of cable material and its cross-section area; $\beta_{m}=\sqrt{2 \frac{G b k_{G}}{h E F}\left[1-\cos \left(\mu_{m}\right)\right]} ; G$ - rigidity modulus of elastic (rubber) rope shell material; $h$ - distance between cables; $b$ - rope thickness; $k_{G}-$ coefficient that considers the influence of rubber shape between the cables on the rigidity of their connection; $A_{m}, B_{m}-$ unknown constants of integration; 1, 2- part number.

In dependencies (4-7) the components, which include constants of integration $A_{m}, B_{m}$, reproduce the mechanism of deviation of deformations and forces from mean values. Their sums are zero, which is a consequence of the equality of the sum of internal forces and external load. Find unknown constants using the conditions of joint deformation of parts (3)

$$
\begin{gathered}
A_{m}=-\frac{\sum_{k=1}^{M-1} \varepsilon_{1, k} \cos \left(\mu_{m}(k-0.5)\right)}{M \beta_{m} e^{\beta_{m} L / 2}} \\
B_{m}=-\frac{\sum_{k=1}^{M-1} \varepsilon_{1, k} \cos \left(\mu_{m}(k-0.5)\right)}{M \beta_{m}}\left(e^{\beta_{m} L / 2}-e^{-\beta_{m} L / 2}\right) .
\end{gathered}
$$

Calculations of internal forces in cables of the fourth part of a part where a rope gets a tubular shape for a rope with parameters matching a rope type RCB-3150 are executed. Fig. 3 shows the graph of a ratio of internal forces to the average force $P=1 \mathrm{kN}$ applied to rope cables. The ratio of actual stresses in the components of machines is the coefficient of stress concentration. Analogically, call the ratio above a coefficient of concentration of forces. The figure shows that internal forces in cables of the middle part of the rope are less than average. They are the smallest in cables with numbers $i \neq \pm 1$, in the crosssection $x=0$. The coefficient of concentration of forces for the considered case in this point is 0.746 . Accord- 


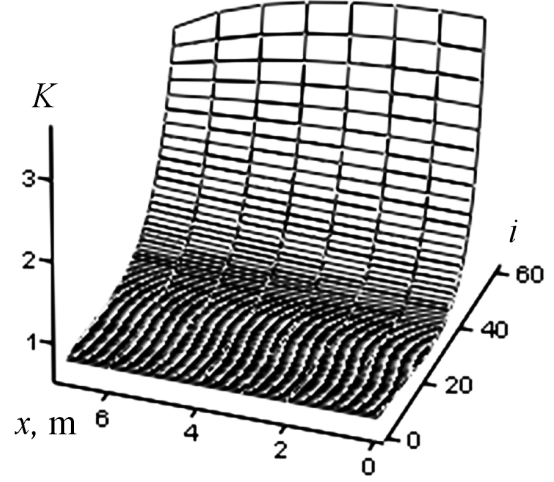

Fig. 3. A surface that reproduces the character of distribution of coefficients of concentration of forces distributed along the $x$-axis between cables with numbers $i$

ingly, in the absence of an external load, compressive forces would occur in them.

Thus, in order to avoid the compression forces of cables to occur, the external load must not be less than the compression force of cables with numbers $i \neq \pm 1$. That is, the following condition must be fulfilled

$$
P M \geq 2 E F \sum_{m=1}^{M-1}\left(\begin{array}{l}
\sum_{k=1}^{M-1} \varepsilon_{1, k} \cos \left(\mu_{m}(k-0.5)\right) \times \\
\times\left(1-e^{-\beta_{m} L / 2}\right)
\end{array}\right) \cos \left(\frac{\mu_{m}}{2}\right) .
$$

According to Fig. 3, internal forces that occur in cables of a symmetrical part of a rope are decreasing. Overload coefficient of the extreme cable decreases from 3.582 in a cross-section of symmetry of the spatial deformation part to 2.765 at its edge. The decreasing character is caused by the influence of adjacent parts of a rope with unchanging cross-section geometry. This is a consequence of a perturbation locality due to a local deformation of rope cables. The manifestation of a local redistribution of forces in a part, which is their source, indicates insignificant length of parts of redistribution of forces. Thus, a deviation of maximum forces from their mean values does not exceed $5 \%$ in cross-sections with coordinates $x= \pm 3 L$. The length of a part where a rope gets a tubular shape is much smaller than its total length. Accepted assumption about boundless parts of a rope with unchangeable shape of cross-sections can be considered acceptable. Obtained results are quite reliable.

Fig. 3 shows that the most loaded are extreme rope cables. Maximum loads are in the cable $M$ in a crosssection $x=0$. It is determined by a dependency

$$
\begin{aligned}
p_{\max }=2 \frac{E F}{M} \sum_{m=1}^{M-1} & \left(\sum_{k=1}^{M-1} \varepsilon_{1, k} \cos \left(\mu_{m}(k-0.5)\right)\left(1-e^{-\beta_{m} L / 2}\right)\right) \times \\
& \times \cos \left(\mu_{m}(M-0.5)\right)+P .
\end{aligned}
$$

According to Hooke's law, the intensity of a tangential force, distributed along the length of a rope, is determined by a dependency

$$
\tau_{i}=\frac{G b}{h} k_{G}\left[u_{i}-u_{i-1}\right], \quad(1 \leq|i| \leq M-1) .
$$

The figure shows the distributed tangential forces transmitted by the rubber in a part where a rope gets a tubular shape.

According to calculations, the maximum tangential distributed forces are not in the extreme rubber layers.

In the process of designing a part where a rope gets a tubular shape, there are problems of determining geometric parameters of such a part - the diameter of a formed pipe and a length of a part of its formation. Diameter of a formed tubular shape is determined by the rope width. In order to obtain the results suitable for comparison, consider a rope type RCB-3150. The length of a part where a rope gets a cylinder shape is $10 \mathrm{~m}$. Change only the amount of cables in it from 20 to 200 (from 10 to 100 cables in a half of the rope). Determine the ratio of the largest to the smallest internal forces of the load of extreme ropes $\left(K_{r}\right)$ for a middle part of a part of rope shape change and in a cross-section on its boundary. The results are shown in Fig. 4.

The given graphic dependency has its maximum at 75 cables. Growth of number of cables for the considered case will not lead to a significant decrease in a relative coefficient $\left(K_{r}\right)$. The specified allows determining the maximum forces in the cross-section, which corresponds to half the length of a transitional part. To apply the indicated conclusions to other types of ropes, it is necessary to determine the length of a transitional part as a value in the expression, $m$

$$
L_{2}=10 \sqrt{\frac{G_{2} b_{2} k_{G_{2}} h_{1} E_{1} F_{1}}{h_{2} E_{2} F_{2} G_{1} b_{1} k_{G_{1}}}} .
$$

In this expression, indexes indicate the attribute of a rope parameter. For the rope RCB-3150 the index is 1 . Index 2 refers to the rope, for which it is necessary to determine the length at which the results shown in Fig. 5 are realized. This is the result of dependency of forces and displacements from the exponent of the product of magnitude of the characteristic index $\beta_{m}$ and coordinate $x$.

The intensity of the maximum tangential forces distributed along the rope length significantly increases with increasing number of cables (Fig. 6).

The analysis shows that as the length of a part where a rope gets a tubular shape increases, the indicators of the stress state decrease as curvature and relative deformations of cables decrease. The results obtained above correspond to the values of the upper boundary of stress.

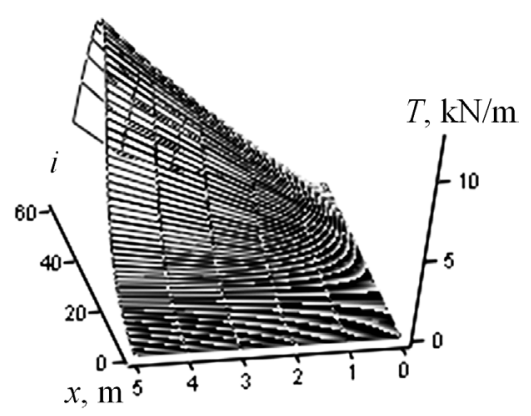

Fig. 4. Distribution of tangential forces transmitted by the rubber in a part where a rope gets a tubular shape 
We considered the case of absolute high compression rigidity of rubber above. Accordingly, we accepted the condition of constant distances between the centers of cross-sections of adjacent cables in a rope. In case of infinitely small compression rigidity of rubber, flexible cables in a part where a rope gets a tubular shape, remain straight. The distances between them decrease, with exception for the cross-sections of the beginning and the end of a part where a rope cross-section changes. Adjacent cables receive different elongations, except for cables located in the middle of a rope. These elongations are smaller than the elongations in the case above. Shear rubber rigidity, as in the previous case, will cause redistribution of forces between the cables. Accordingly, the relative elongations of cables, their mutual shear will take smaller possible values.

Projections of axes of cables on a plane normal to the axis of the rope are shown in Fig. 7 with solid straight lines.

For comparison, dash lines also show the projections of cylinders formed by the corresponding equidistant evolvents and on which cables are located, provided the constant distances between them. Known lengths of projections of cables and the length of a part where a

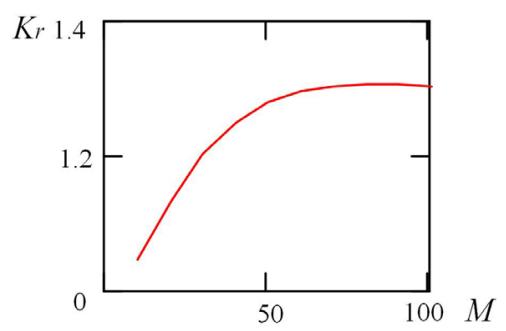

Fig. 5. Dependency of a relative coefficient $\left(K_{r}\right)$ on the amount of cables in a rope $M$

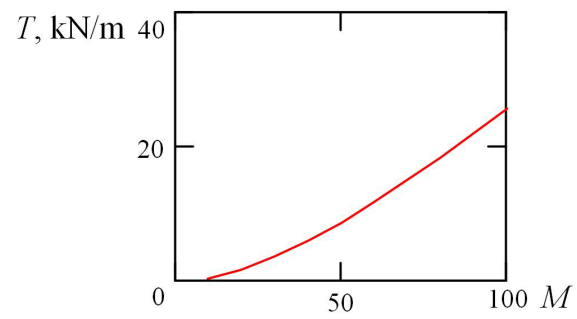

Fig. 6. Dependency of intensities of maximum tangential forces distributed along the rope length on the number of cables in it

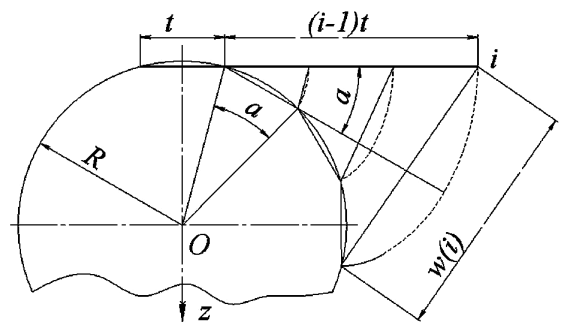

Fig. 7. Projection of a rope and its axes centers on a plane, normal to the axis of a rope rope gets a tubular shape allow determining the relative elongations of cables

$$
\varepsilon_{2, \pm i}=\frac{\left(\begin{array}{l}
{\left[\cos \left(\frac{a}{2}\right)-\cos \left(\left(i-\frac{1}{2}\right) a\right)\right]^{2}+} \\
+\left[\left(i-\frac{3}{2}\right) \frac{t}{R}-\sin \left(\left(i-\frac{1}{2}\right) a\right)\right]^{2}, \\
\left(i-\frac{1}{2}\right) a \leq \frac{\pi}{2} \\
{\left[\begin{array}{l}
\left.\cos \left(\frac{a}{2}\right)-\cos \left(\left(i-\frac{1}{2}\right) a-\frac{\pi}{2}\right)\right]^{2}+ \\
{\left[\left(i-\frac{3}{2}\right) \frac{t}{R}-\sin \left(\left(i-\frac{1}{2}\right) a\right)\right]^{2},} \\
\left(i-\frac{1}{2}\right) a>\frac{\pi}{2}
\end{array}\right.}
\end{array} .+L^{2}-L\right.}{L} .
$$

Relative elongations (11), as well as elongations (1), increase upon the increase of nominal values of cable numbers from zero - for cables with numbers $i \neq \pm 1$. Boundary conditions (2) determine the conditions of loading and deformation of ropes in cross-sections $x=0$, $x \rightarrow \infty$. They have not changed, as well as a condition of joint deformation of parts (3). Leave accepted forms of solutions (4-7) unchanged. Recalculations lead to forms of rope stress state similar to expressions $(8-10)$. The only difference is that instead of the relative extensions $\varepsilon_{1, i}$ in the upper-mentioned expressions it is necessary to substitute for $\varepsilon_{2, i}$. Insignificant difference in dependencies of rope stressed states for extreme cases of rigidity of rubber layers determines their qualitative coincidence. Thus, minimum force concentration coefficient (in cables numbered $i \neq \pm 1$, in cross-section $x=0$ ) $K=0.821$, whereas in the previous case -0.746 . Differences between the forces and stresses that occur at boundary rigidity for rubber layers related to maximum values are 35 and $44 \%$.

Considering two cases of a deformed state of a rope with extreme values of rigidity of rubber layers, located between cables, we can make the following inequality

$$
\begin{gathered}
\sum_{m=1}^{M-1}\left(\sum_{k=1}^{M-1} \varepsilon_{1, k} \cos \left(\mu_{m}(k-0.5)\right)\left(1-e^{-\beta_{m} L / 2}\right)\right) \times \\
\times \cos \left(\mu_{m}(M-0.5)\right) \geq \frac{\left(P_{a d}-P\right) M}{2 E F} \geq \\
\geq \sum_{m=1}^{M-1}\left(\sum_{k=1}^{M-1} \varepsilon_{2, k} \cos \left(\mu_{m}(k-0.5)\right)\left(1-e^{-\beta_{m} L / 2}\right)\right) \times \\
\times \cos \left(\mu_{m}(M-0.5)\right) .
\end{gathered}
$$

The resulting inequality (12) allows determining the possible boundaries of values of additional force $P_{a d}$ that occurs in the most loaded rope cables in a part where a rope gets a tubular shape.

Shear rigidity of rubber layers depends on a cable placement spacing in a rope. It infinitely increases with decreasing of a cable placement spacing to a mini- 
mum, equal to a diameter of cables. In rubber-cable ropes, provided that the rope weight is minimized, smaller cable placement spacing is used. The values of maximum cable tension forces in rubber-cable ropes are closer to the upper limit. The functional purpose of conveyor belts is dual. They perform the function of carrying the transported object on the belt during movement, and also transfer the traction force. The latter raises the problem of appropriateness of use of ropes with increased cable placement spacing. Increasing the thickness of a rubber layer between the cables reduces compressive rigidity of rubber and leads to a decrease in values of extreme tension forces of cables.

The condition of constant shape of all cables must be fulfilled together with a condition of strength. The fulfillment of the condition is possible by preventing the occurrence of compression forces of cables - the fulfillment of condition (8), considering the value of relative elongation described by dependency (11).

Rope is shaped into a tube via connecting its edges by special locks. The pulling capacity of a rope, including one of tubular shape, is ensured by its design, in particular the number of cables in it. Rope cable breakage is possible during operation. Breakage also affects strength of a rope. Strength loss caused by cable breakage must be taken into account when allocating a safety margin to avoid emergency situations.

Determine the stress-strain state of such tubularshaped rope with a broken random cable $k$. Trace a plane through the axis of this cable and the axis of the tubular rope. It divides the tubular rope into two symmetrical parts. In case when the number of cables $M$ is not even, the plane will pass in the middle between the cables, as shown in Fig. 8. Taking this into account, consider a rope, which consists of an odd number of cables $M$. Number the cables from one to $M$.

Unfold this cut tubular rope. As a result, we have a stress-strain state of the rope that is symmetrical relatively to the broken cable. Displacements and loads of cables with numbers 1 and $M$ are the same. Shear stress in a rubber layer between them is absent. This shows that the breakage of any single cable leads to an identical stress state of the rope of tubular shape, relatively to a location of the cable. This state according to the computable model is characterized by the fact that specifically the middle cable is always broken. This allows us to apply a known form of solution for determining the SSS of a tubular tractive rope with a broken cable

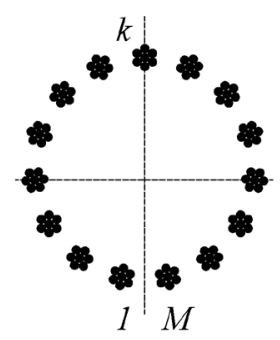

Fig. 8. Cross-section of a tubular-shaped rubber-cable rope

$$
\begin{gathered}
u_{i}=\sum_{m=1}^{M-1}\left(A_{m} e^{\beta_{m} x}+B_{m} e^{-\beta_{m} x}\right) \times \\
\times \cos \left(\mu_{m}(i-0.5)\right)+\frac{P}{E F M} x+c ; \\
p_{i}=E F \sum_{m=1}^{M-1}\left(A_{m} e^{\beta_{m} x}-B_{m} e^{-\beta_{m} x}\right) \beta_{m} \times \\
\times \cos \left(\mu_{m}(i-0.5)\right)+\frac{P}{M}, \quad 1 \leq i \leq M ; \\
\tau_{i}=\frac{G b k_{G}}{h} \sum_{m=1}^{M-1}\left(A_{m} e^{\beta_{m} x}+B_{m} e^{-\beta_{m} x}\right) \times \\
\times\left(\cos \left(\mu_{m}(i+0.5)\right)-\cos \left(\mu_{m}(i-0.5)\right)\right), \\
1 \leq i \leq M-1,
\end{gathered}
$$

where $c$ - unknown constant.

Consider a rope loaded with an external force $P$ as infinitely long one with a broken cable in the middle. Place the start of $x$-axis in a cross-section of cable breakage. Given the symmetry, consider a part of the rope in an interval $0 \leq x \rightarrow \infty$. The condition of symmetry indicates that in the cross-section $x=0$ there is no cable displacement except for the broken one. Edges of the broken cable are not loaded. Given the infinite growth of coordinate $x$, internal resistance forces of cables and displacements of their cross-sections cannot grow infinitely. Formulate this as boundary conditions

$$
\begin{gathered}
x=0, \quad u_{i}=0, \quad(i \neq k), \\
\frac{\partial u_{k}}{\partial x}=0, \quad(i=k), \\
x \rightarrow \infty, \quad u_{i} \rightarrow \text { const }, \\
\frac{\partial u_{i}}{\partial x} \rightarrow \text { const } .
\end{gathered}
$$

The last condition is provided by accepting $A_{m}=0$. Consider that dependencies (13-15) are constructed using cable numbers as a discrete coordinate axis. The boundary condition (16) has a form of a discontinuous - delta function. Take this into consideration. Calculate unknown constants in the form

$$
\begin{gathered}
B_{m}=\frac{P \cos \left(\mu_{m}(k-0.5)\right)}{M E F \sum_{m=1}^{M-1} \cos \left(\mu_{m}(k-0.5)\right)^{2} \beta_{m}} ; \\
c=\frac{P}{2 M E F \sum_{m=1}^{M-1} \cos \left(\mu_{m}(k-0.5)\right)^{2} \beta_{m}},
\end{gathered}
$$

where $P$ - average internal force in rope cables.

Displacements of cross-sections of cables, internal forces and tangential stresses that occur in them when a single cable breaks depend on the number of cables and the properties of rope components according to expressions (13-15). Figs. 9 and 10 show the dependencies of maximum values of coefficients of uneven distribution of forces $K$ and values of distribution intensity of tangen- 
tial forces $T$ in layers of rubber, located between cables on the number of cables in a rope $M$.

According to graphic dependencies (Figs. 9, 10), the maximum forces and tangential stresses are significantly dependent on the number of cables in a rope, if it is less than ten. This is a consequence of a local influence of a cable breakage on the stress-strain state of a tubular rope and the implementation of St. Venant's principle about the locality of influence of local load changes or a component design.

Consider the redistribution of forces across the width of a rope, depending on the number of cables in it. Fig. 11 shows the distribution of forces in a cross-section of a rope with different number of cables $M$ in case of the middle cable breakage.

In the figure, the number of cables is conditionally unchanged and is nineteen. The actual number of cables which is from two to eighteen was supplemented by conditional cables. Coefficients of forces concentration in imaginary cables are equal to zero. The figure shows that the growth of the number of cables in a tubular rope does not significantly affect the redistribution of forces between them. The same conclusion can be reached by examining problems regarding the quantitative part of the force perceived by adjacent cables from the value of the force that was perceived by the broken cable before its breakage. The indicated dependency is shown in Fig. 12.

The graph shows the quantitative dependency of a force part transmitted by the broken cable before its breakage from the number of cables in a rope. The middle cable takes place with an odd number of cables. The minimum number of cables in a rubber-cable rope is three. In this case, damage to one cable can lead to an additional load of only two cables. And just these cables

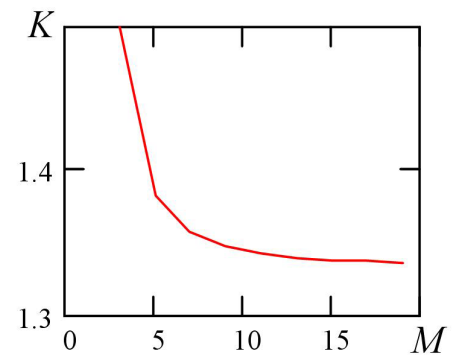

Fig. 9. Dependency of maximum values of coefficients of uneven distribution of forces $K$ on the number of $c a-$ bles in a rope $M$

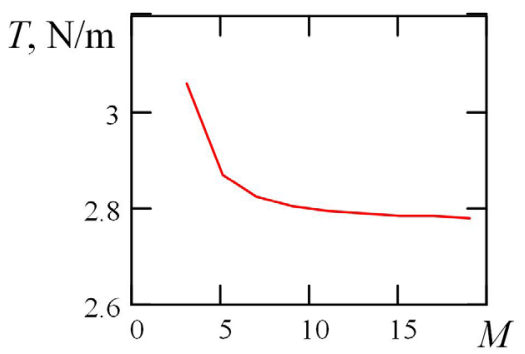

Fig. 10. Dependency of distribution intensity of tangential forces $T$ in layers of rubber, located between cables on the number of cables in a rope $M$

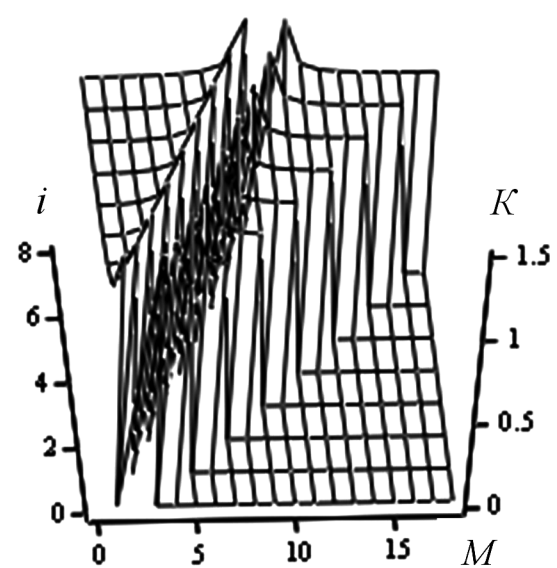

Fig. 11. Distribution of coefficients of forces concentration in ropes with $M$ cables in case of the middle cable breakage

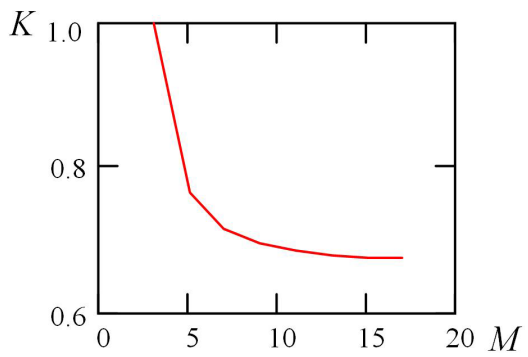

Fig. 12. Relative load part, perceived by two cables adjoining the middle broken one in a rope with $M$ cables

take the load that occurred in the broken cable before its breakage. Accordingly, if there are only three cables in a tubular-shaped rope, cables adjacent to the broken one will take the entire load; coefficient $K=1$. As the number of cables increases, the mentioned proportion decreases and does not get lower than 0.6.

Established dependencies of maximum values of coefficients of uneven distribution of forces $K$, tangential forces $T$ in layers of rubber, located between the cables on the number of cables in a rope $M$, caused by the breakage of any cable of a flat rubber-cable rope, which gets a tubular shape, allow taking into account possible cable breakages during the design of lifting and transporting machines with a rubber-cable tractive rope of a tubular shape.

The basis of a rubber-cable rope is cables. They are made of a twisted cable system. This structure of a cable leads to a distribution of a twisting moment while stretching throughout cable length. To avoid a twisting moment in a rope an even number of cables is used. Cables of opposite twist directions are arranged alternately in the rope. The balance of a rope is disturbed due to cable breakage. The locality of redistribution of forces in case of cable breakage leads to localization and distributed rope twisting moment. Assume that a cable twisting moment is directly proportional to the internal force of its load with a coefficient of proportionality $\gamma$. Determine a value of intensity of an unbalanced moment of a rope in the cross-section of cable breakage and in the cross-section which is remote from it by $0.5 \mathrm{~m}$. Fig. 13 shows dependencies of an unbalanced moment, related to an aver- 


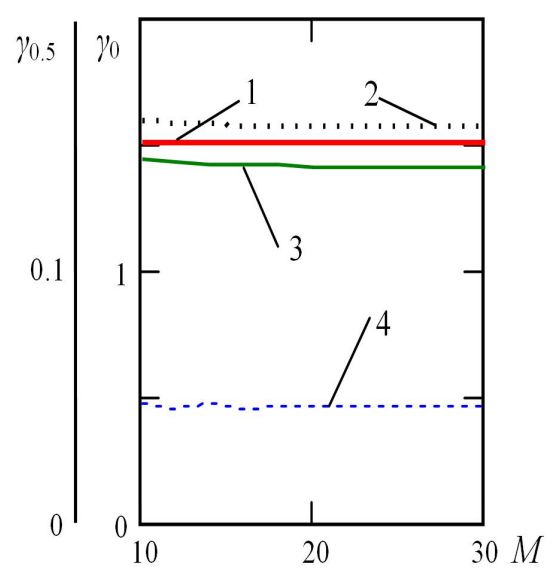

Fig. 13. Relative twisting moment of a rope with $M$ cables in the cross-section of cable breakage $\gamma_{0}$ and $\gamma_{0,5}$ at a distance of $0.5 \mathrm{~m}$ :

1 - in the cross-section of extreme cable breakage; 2 - in the cross-section of middle cable breakage; 3 - in the crosssection at a distance of $0.5 \mathrm{~m}$ from the cross-section of extreme cable breakage; 4 - in the cross-section at a distance of $0.5 \mathrm{~m}$ from the cross-section of middle cable breakage

age load force of cables on their number in a rope. The values of moments are shown for breakage cases of the extreme cable and the most distant cable from the edge.

The figure shows insignificant dependence of maximum intensity of rope twisting moment on the location of a cable in it (when an extreme or a middle cable is broken) in the breakage cross-section (curves 1 and 2). The placement of a broken cable in a rope affects the length of a part of stress-strain state perturbation more significantly (curves 3 and 4 ). Thus, in case of breakage of a cable that is the farthest from the edges of a rope, the intensity of the unbalanced moment in a rope system is close to $10 \%$ of its maximum value (curve 4 ). A similar indicator is practically twice as large for a case of an extreme cable breakage (curve 3). This feature is fulfilled because the intensity of distributed twisting moments of a rope at a distance of $0.5 \mathrm{~m}$ is one order of magnitude lower than their values in a part of cable breakage.

This character of distribution of moments of imbalance of system of cable ropes is caused by the placement scheme of cables with the opposite twisting direction. The twist direction determines the direction of twisting moment. Breakage of the extreme cable leads to a significant increase in the internal tensile force of only one adjacent cable. Non-extreme cable breakage leads to growth of internal tensile forces of two adjacent cables. In this case, as shown above, adjacent cables perceive at least $60 \%$ of a cable load, which it perceived before the breakage. A similar ratio is accurate in case of extreme cable breakage. As a result, the breakage of one cable significantly increases twisting moments of adjacent cables.

According to a scheme of alternating placement of cables of the opposite direction the moments of one direction increase substantially (at least by $60 \%$ ). It is possible to decrease the mentioned growth provided the forces are distributed between the cables of the opposite direction. This distribution can be arranged in such a way that, any cable is adjacent to two other cables of the op- posite twist direction. This can be ensured by placing cables in a rope according to a scheme, where two cables of one direction are alternately placed with pairs of cables of another twisting direction. Fig. 14 shows the dependencies similar to those shown in Fig. 13, but in a scheme of alternate placement of cable pairs of one twist direction.

According to Fig. 14, the placement of a broken cable in a rope more significantly affects the values of maximum intensity of a rope twisting moment (curves 1 and 2). At the same time, the maximum values during the middle cable breakage are almost one third less. In case of the extreme cable breakage, this indicator reaches $50 \%$.

Reduction of a twisting moment in the cross-section of cable breakage is accompanied by an increase in length of a perturbation part. Thus, in case of extreme cable breakage, an unbalanced twisting moment at a distance of $0.5 \mathrm{~m}$ from the cross-section of breakage decreased to $0.25 \gamma$. In case of middle cable breakage, practically, down to $0.1 \gamma$ which is 2.5 and two times more than in a previous case. The specified confirms an increase in length of imbalance occurrence part to rope twisting.

The balancing of cable twisting moments happens due to the occurrence of additional deformations and stresses in a rubber of a rope. Reduction of intensities of maximum twisting moments of a rope leads to a decrease of stresses in rubber and improvement of its operation conditions. But keep in mind that in a rope with a scheme of alternate placement of cable pairs of one twisting direction the number of cables must be a multiple of four.

Conclusion. Determination in analytical form of boundaries of a stress-strain state of a rope which gets a tubular shape, that occur including the case of broken cables, establishment of a mechanism of a rope balance disturbance to twisting, implementation of the system of cable placement in a rope as two cables of one twist direction after two cables of an opposite twist direction, allow reasonable choosing of the parameters of a rope of lifting and transporting machines, in which a rope gets a

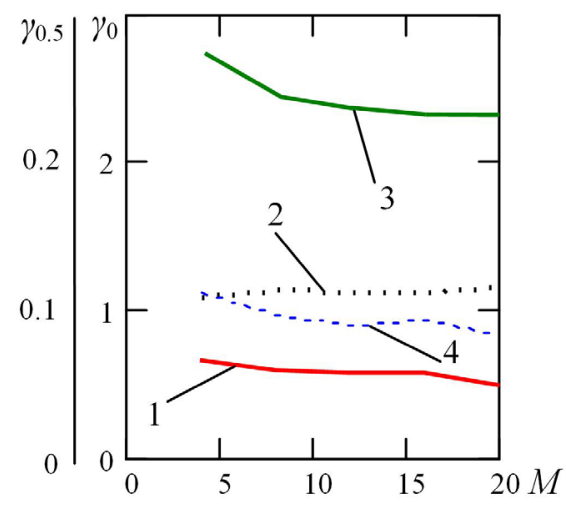

Fig. 14. Relative twisting moment of a rope with $M$ cables in the cross-section of cable breakage $\gamma_{0}$ and $\gamma_{0,5}$ at a distance of $0.5 \mathrm{~m}$ in a scheme of alternate placement of cable pairs of one twisting direction:

1 - in the cross-section of extreme cable breakage; 2 - in the cross-section of middle cable breakage; 3 - in the crosssection at a distance of $0.5 \mathrm{~m}$ from the cross-section of extreme cable breakage; 4 - in the cross-section at a distance of $0.5 \mathrm{~m}$ from the cross-section of middle cable breakage 
cylinder shape. This ensures its operation safety and contributes to solving the problem of ecological compatibility of underwater oil extraction.

\section{References.}

1. Vayenas, N. and Peng, S., 2014. Reliability analysis of underground mining equipment using genetic algorithms: A case study of two mine hoists. Journal of Quality in Maintenance Engineering, 20(1), pp. 32-50.

2. Styp-Rekowski, M., Manka, E., Matuszewski, M., Madej, M. and Ozimina, D., 2015. Tribological problems in shaft hoist ropes wear process. Industrial Lubrication and Tribology, 67(1), pp. 47-51.

3. Ilin, S. R., Samusia, V. I., Ilina, I. S. and Ilina, S. S., 2016. Influence of dynamic processes in mine hoists on safety exploitation of shafts with broken geometry. Naukovyi Visnyk Natsionalnoho Hirnychoho Universytetu, 3, pp. 42-47.

4. Zabolotny, K.S., Zhupiiev, O. L. and Sosnina Ye. M., 2012. Study of deflected mode of mine winder split drums. Naukovyi Visnyk Natsionalnoho Hirnychoho Universytetu, 1, pp. 82-87. Available at: <http://nv.nmu.org. ua/index.php/ru/component/jdownloads/finish/ 31-01/453-2012-01-zabolot/0> [Accessed 11 April 2017]. 5. Bass, K. M., Kuvayev, S. M., Plakhotnik, V.V. and Krivda, V.V., 2014. Planar and spatial mathematical motion simulation of open pit mining vehicles. Naukovyi Visnyk Natsionalnoho Hirnychoho Universytetu, 3, pp. 60-65. 6. Protsiv, V.V., Ziborov, K.A. and Fedoriachenko, S.A., 2013. On formation of kinematical and dynamical parameters of output elements of the mine vehicles in transient motion. Naukovyi Visnyk Natsionalnoho Hirnychoho Universytetu, 4, pp. 64-68.

7. Shpachuk, V.P., 2016. Effect of mutually amplifying action of two coordinate shock loading in problems of dynamics of knots of machine. Naukovyi Visnyk Natsionalnoho Hirnychoho Universytetu, 6, pp. 89-94.

8. Samusya, V. I., Oksen, Y. I. and Radiuk, M. V., 2013. Heat pumps for mine water waste heat recovery. Annual Scientific-Technical Collection - Mining of Mineral Deposits, pp. 153-157.

9. Pivnyak, G., Dychkovskyi, R., Smirnov, A. and Cherednichenko, Yu., 2013. Some aspects on the software simulation implementation in thin coal seams mining. Energy Efficiency Improvement of Geotechnical Systems [online], pp. 1-10.

10. Zabolotny, K. and Panchenko, Y., 2010. Definition of rating loading in spires of multilayer winding of rubberrope cable. New Techniques and technologies in Mining [online], pp. 223-229. Available at: <https://www.taylorfrancis.com/books/9780203093351> [Accessed 22 July 2017]. 11. Kolosov, D., Dolgov, O. and Kolosov, A., 2013. The stress-strain state of the belt on a drum under compression by flat plates. Annual Scientific-Technical Collection - Mining of Mineral Deposits, pp. 351- 357.

12. Grujić, M. and Erdeljan, D., 2014. Advantages of high angle belt conveyors (hac) in mining. Applied Mechanics and Materials, 683, pp. 73-77.

13. Bondarenko, A. A., 2012. Mathematical modeling of soil dredger absorption processes in the underwater bottomhole. Metallurgical and Mining Industry [online], 3, pp. 79-81. Available at: <http://www.metaljournal. com.ua/read/ru/2012/3/> [Accessed 11 April 2017].

14. Bondarenko, A. A. and Zapara, Ye. S., 2012. Laws of determination of fine materials suction limits in submarine suction dredge face. Naukovyi Visnyk Natsionalnoho Hirnychoho Universytetu, 4, pp. 59-64. Available at: <http://nv.nmu.org.ua/index.php/ru/component/ jdownloads/finish/34-04/537-2012-4-bondarenko/0> [Accessed 14 April 2017].

15. Kyrychenko, Y., Samusia, V., Kyrychenko, V. and Goman, O., 2012. Experimental investigation of aeroelastic and hydroelastic instability parameters of a marine pipeline. Geomechanical Processes During Underground Mining - Proceedings of the School of Underground Mining [online], pp. 163-167. Available at: $<$ http://www.crcnetbase.com/doi/abs/10.1201/b1315728> [Accessed 1 May 2017].

16. Kyrychenko, Y., Samusia, V. and Kyrychenko, V., 2012. Software development for the automatic control system of deep water hydrohoist. Geomechanical Processes During Underground Mining - Proceedings of the School of Underground Mining [online], pp. 81-86. Available at: <http://www.crcnetbase.com/doi/abs/10.1201/ b1315714> [Accessed 7 May 2017].

17. Kolesnik, V.Ye., Kulikova, D. V. and Pavlichenko, A. V., 2016. Substantiation of rational parameters of perforated area of partitions in an improved mine water settling basin. Naukovyi Visnyk Natsionalnoho Hirnychoho Universytetu, 6, pp. 120-127.

18. Belmas, I. V., Kolosov, D. L. and Bobylova I.T., 2012. Dniprodzerzhinsk technical university, The device for environment protection from casing pipes leakage in water mass. Ukraine. Pat. 75145.

19. Belmas, I. V., Kolosov, D. L. and Kolosov, A. L., 2014. Study of stressed-deformed state of rubber-rope cable in the area of tubular transformation. Bulletin of PNRPU. Geology. Oil \& Gas Engineering \& Mining, 12, pp. 48-55. DOI: 10.15593/2224-9923/2014.12.6.

\section{Напружено-деформований стан гумотросового тягового органа трубчатої форми}

\section{І. В. Бельмас ${ }^{1}$, Д. Л. Колосов ${ }^{2}$, О. Л. Колосов ${ }^{3}$, С. В. Онишенко ${ }^{2}$}

1 - Дніпровський державний технічний університет, м. Кам'янске, Україна, е-mail: belmas09@meta.ua 2 - Державний вищий навчальний заклад „Національний гірничий університет“, м. Дніпро, Україна, e-mail: evolyuta@gmail.com

3 - ЗАТ „Константа“, м. Корольов, Російська Федерація, e-mail: globoid@mail.ru

Мета. Встановлення залежностей напруженодеформованого стану гумотросового каната від його механічних характеристик і геометричних параметрів ділянки надання плоскому канату циліндричної форми з урахуванням впливу розривів тросової основи.

Методика. Побудова методами механіки композитних матеріалів аналітичних моделей взаємодії 
тросів у гумотросовому канаті як композитній структурі, утвореній з регулярно розташованих в одній площині паралельних тросів, що взаємодіють через шар гуми. Отримання в замкненому вигляді аналітичних залежностей для встановлення параметрів напружено-деформованого стану каната на ділянці надання йому трубчатої форми, що дозволяють визначати верхню й нижню межу напружень у тросах і гумовому прошарку каната. Математичний опис процесу базується на засадах механіки шаруватих конструкцій із жорсткими та м'якими шарами.

Результати. Розроблені й досліджені дві математичні моделі, що дозволяють визначати межі напружено-деформованого стану плоского гумотросового каната, якому надана просторова форма циліндру. Отримані результати дають змогу з високим рівнем достовірності прогнозувати експлуатаційні властивості каната, включно з розривами тросів його армування.

Наукова новизна. Для крайніх значень характеристик жорсткості гумового міжтросового шару отримані й розв'язані аналітичні залежності, що дозволяють визначати основні характеристики напружено-деформованого стану каната, якому на обмеженій довжині надана трубчата форма, включно й у разі розриву тросової основи.

Практична значимість. Можливість визначення меж напружено-деформованого стану каната, прогнозування його напруженого стану в разі розриву троса у процесі експлуатації дозволяє обгрунтовано обирати параметри підйомно-транспортних машин, на яких канату надається трубчата форма. Це підвищує рівень безпеки їх використання й сприяє розв'язанню проблеми екологічності видобутку нафти підводним способом за рахунок іiї відведення із зони пошкодження свердловини безпосередньо порожниною каната, якому надана циліндрична форма, та до якого приєднано масивну нафтоприймальну конструкцію.

Ключові слова: плоский гумотросовий канат, перехідна ділянка каната, поздовжне навантаження, розрив тросової основи, напружено-деформований стан, підйомно-транспортна машина

\section{Напряженно-деформированное состояние резинотросового тягового органа трубчатой формы}

\section{И. В. Бельмас ${ }^{1}$, Д. Л. Колосов ${ }^{2}$, А. Л. Колосов ${ }^{3}$,} С. В. Онищенко

1 - Днепровский государственный технический университет, г. Каменское, Украина, e-mail: belmas09@meta.ua 2 - Государственное высшее учебное заведение „Национальный горный университет“, г. Днепр, Украина, e-mail: evolyuta@gmail.com

3 - ЗАО „Константа“, г. Королев, Российская Федерация, e-mail: globoid@mail.ru
Цель. Установление зависимостей напряженнодеформированного состояния резинотросового каната от его механических характеристик и геометрических параметров участка придания плоскому канату цилиндрической формы с учетом влияния разрывов тросовой основы.

Методика. Построение методами механики композитных материалов аналитических моделей взаимодействия тросов в резинотросовом канате как композитной структуре, образованной из регулярно расположенных в одной плоскости параллельных тросов, взаимодействующих через слой резины. Получение в замкнутом виде аналитических зависимостей для установления параметров напряженно-деформированного состояния каната на участке придания ему трубчатой формы, позволяющих определять верхнюю и нижнюю границу напряжений в тросах и резиновой прослойке каната. Математическое описание процесса базируется на принципах механики слоистых конструкций с жесткими и мягкими слоями.

Результаты. Разработаны и исследованы две математические модели, позволяющие определять границы напряженно-деформированного состояния плоского резинотросового каната, которому придана пространственная форма цилиндра. Полученные результаты позволяют с высокой степенью достоверности прогнозировать эксплуатационные свойства каната, включительно с разрывами тросов его армировки.

Научная новизна. Для крайних значений характеристик жесткости резинового межтросового слоя получены и решены аналитические зависимости, позволяющие определять основные характеристики напряженно-деформированного состояния каната, которому на ограниченной длине придана трубчатая форма, включительно и в случае разрыва тросовой основы.

Практическая значимость. Возможность определения границ напряженно-деформированного состояния каната, прогнозирование его напряженного состояния в случае разрыва троса в процессе эксплуатации позволяет обоснованно выбирать параметры подъемно-транспортных машин, на которых канату придается трубчатая форма. Это повышает уровень безопасности их использования и способствует решению проблемы экологичности добычи нефти подводным способом за счет ее отвода из зоны повреждения скважины непосредственно полостью каната, которому придана цилиндрическая форма, и к которому присоединена массивная нефтеприемная конструкция.

Ключевые слова: плоский резинотросовый канат, переходной участок каната, продольная нагрузка, разрыв тросовой основы, напряженно-деформированное состояние, подбемно-транспортная машина

Рекомендовано до публікації докт. техн. наук B. A. Ропаєм. Дата надходження рукопису 12.02.17. 